\title{
Determination of critical flow velocity for tube- bundle with application of numerical investigation method
}

\author{
Alexey Samolysov, \\ Saveliy Kaplunov, \\ Natalia Valles, \\ Olga Marchevskaya, \\ Elena Dronova \\ IMASH RAS, \\ Maliy Haritonievskiy Line 4, \\ 101990 Moscow, Russia \\ E-mail:kaplunov@imash.ru, \\ klevdr54@mail.ru
}

The work is devoted to the creation and application of mathematical models for the most dangerous oscillation excitation mechanisms of tubes and cylindrical form bluff structures in liquid or gas flow, as well as to the creation of efficient computational methods for description of these models.

A numerical investigation method of hydrodynamic forces arising from a separated flow and tube-bundle oscillations excited by these forces was developed by the authors.

The method is based on the application of created original tube-bundle hydroelastic oscillation excitation in a cross-flow mathematical model. Hydroelastic excitation problem is reduced to the stability analysis of undisturbed state of elastic tubes. Analysis is conducted with the assumption of linearity of the destabilizing forces. On the basis of the mathematical model, the necessary and sufficient condition for the stability, expressed through the dimensionless system parameters (mass, damping, velocity), was obtained.

Numerical identification of the linear hydrodynamic connection matrix algorithm for particular tube-bundles was elaborated. Verification of algorithm and programs based on it was performed by results of simulations and available experimental data correlation.

A method for determination of a linear hydrodynamic connection matrix for tube-bundles with a regular arrangement of the cross-section was offered. It is based on computation of a relatively small, but sufficient for reliable results, part of the tube-bundle.

Key words: tube-bundle, numerical experiment, hydroelastic excitation, separated flow, linear hydrodynamic connection matrix

\section{PROBLEM STATEMENT}

The work is devoted to the creation and application of mathematical models for the most dangerous oscillation excitation mechanisms for tubes and cylindrical form bluff structures in liquid or gas flow, as well as to the creation of efficient computational methods for description of these mod- els. A combined approach based on correlation of the numerical experiment and investigation of nature objects is necessary for the problem solution.

Work objective is the creation and implementation of viscous liquid and gas flow effective modelling methods in form of program complexes for investigation of aerodynamic loads on bodies, performing voluntary movements, including change 
in shape, for solution of conjugate bodies motion problems under action of aerodynamic forces.

\section{EXCITATION MECHANISMS}

Based on experimental data by Zukauskas [1] there are several specific mechanisms of excitation: turbulence, periodic vortex separation, hydroelastic excitation (Fig. 1), where $d$ is diameter of tubes, $f_{n}^{0}$ is natural frequency of each tube, $U$ is flow velocity, $A_{y}$ is RMS amplitude vibration.

It is shown that the possibility of hydroelastic excitation is the spoilage warning for a tube bundle. Instability region occurs when velocity of flow exceeds some critical parameter (named by critical velocity).

Primarily during development engineering, it is essential to appraise the possibility of tube-bundle hydroelastic excitation, and only after its exclusion, oscillation amplitudes caused by hydroelastic excitation calculation make sense.

\section{APPLIED METHODS}

Carrying out this work, the following methods were applied: modernized method of discrete vortices (MMDV), viscous vortex domain method, conformal transformation method, collocation method, multicomponent system estimation with application of a linear hydrodynamic connection matrix, multicomponent system stability analysis with Lyapunov criterion, decomposition of a potential func- tion by small parameter method, finite-difference methods, statistical modelling and optimization method, similarity and dimensional analysis theory.

The main method applied in this work is the original and efficient modernized method of discrete vortices (MMDV, created in IMASH RAS) $[2,3]$, which makes it possible to solve a wide range of tasks for flow of stiff and flexible bodies of different configuration of cross-section in a specified range of Reynolds numbers during the numerical experiment. This method application was approved by known physical experimental data. Under this method, determination of aerodynamic forces acting on the moving parts and multicomponent infrastructure system constructions (bridges, pedestrian bridges, tube constructions, and elastic station constructions), as well as the calculation of construction self-oscillations with the passage of highspeed trains in $2 \mathrm{D}$ statement were worked out.

\section{OBTAINED MODEL HIERARCHY}

As shown by long experience modelling with the method of discrete vortices, the created model possesses the following advantages. On a consolidated mathematical and computational basis, one can create a hierarchy of software covering a wide range of applications. Based on this, in combination with the physical experiment accumulation of an important cognitive experiment, the limits of scheme and model applicability are set. This establishes a transition from individual tasks to the creation

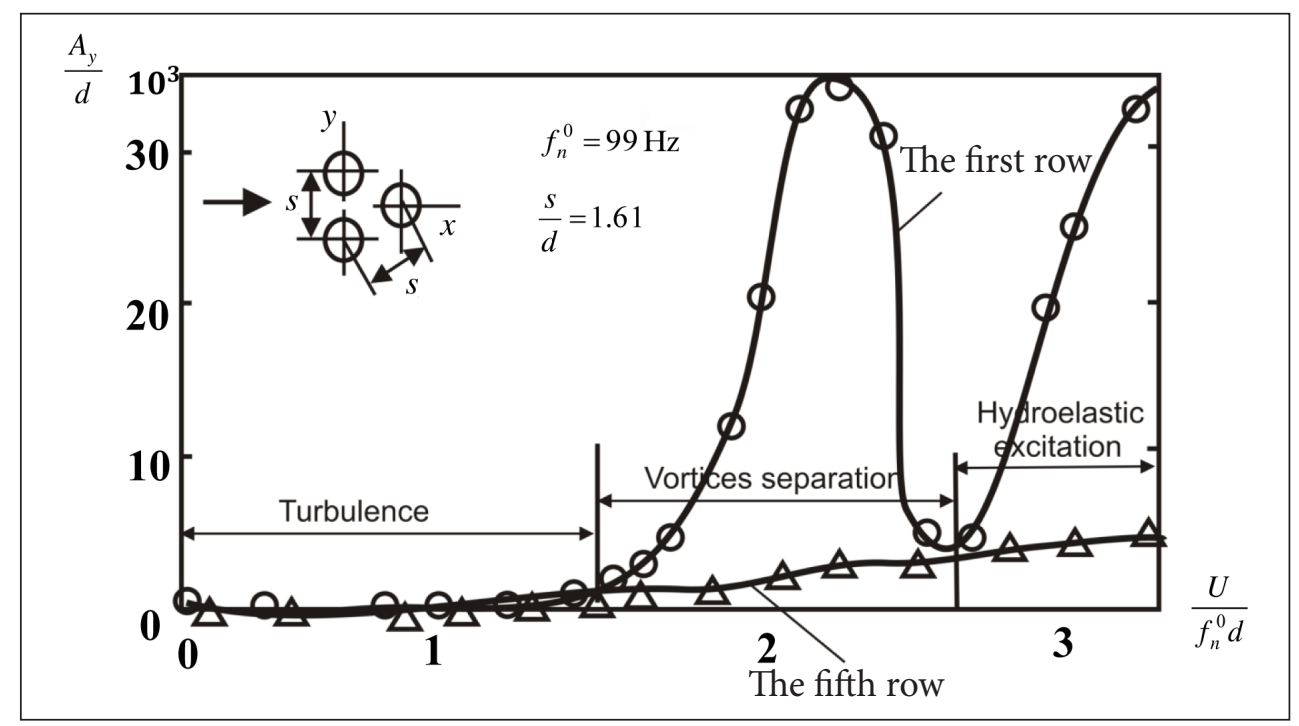

Fig. 1. Typical amplitude-velocity characteristics for the tube-bundle in cross-flow. Experimental data by Zukauskas [1] 
of complex tasks on a regular basis. It turned out that the method of addition of discrete vortices with a boundary layer model (to determine its separation) allows one to make a new step in empowering the discrete vortex method (expanding opportunities). Change in the vortex separation angle enables one to simulate the impact of Re-number on the hydrodynamic forces and vortex separation arrangement; consequently, the method of discrete vortices was extended to the Re-numbers area from $10^{2}$ to $10^{6}$. In the computation effect of resistance $C_{x}, C_{y}$ crisis was reproduced for $R e$-numbers $R e>2 \cdot 10^{5}$.

The original boundary problem solution allowed applying a combined method to extend the discrete vortex method to the calculation of bodies with an arbitrary (non-circle) cross-section flow.

The joint equation system solution describing the body oscillations and defining corresponding hydrodynamic forces at each step of the calculation allowed applying a modernized method of discrete vortices for the calculation of self-oscillations of different constructions.

\section{HYDROELASTIC EXCITATION}

The mathematical model of the hydroelastic interaction, where interaction between oscillating tubes is taken into account in the most common form (in framework of destabilizing forces linearity hypothesis), is given in $[4,5]$ (Fig. 2), where $A$ is amplitude vibration, $D$ is diameter of tubes, $U$ is flow velocity, $f$ is natural frequency of each tube. The model describes a hydroelastic excitation mechanism as instability of the development of unperturbed state of elastic tubes

\section{MATHEMATICAL DESCRIPTION OF THE NUMERICAL EXPERIMENT FOR DETERMINATION OF CRITICAL VELOCITY}

It is assumed that the bundle vibrates in one of its natural mode shapes. Let us confine the study by examination of flexural vibrations by one of the first shapes without specifying the conditions of ends of elastic tube fixing.

Then, the solution of tube oscillation equation system can be presented in the following form:

$$
\bar{w}(t, z)=a \bar{X}\left(\frac{t u}{2 R}\right) \Psi\left(\frac{\gamma z}{l}\right),
$$

where $\bar{X}=\operatorname{col}\left(x_{1}, y_{1}, \ldots, x_{n}, y_{n}\right)-2 \mathrm{~N}$ is dimensional position vector of tubes from the unperturbed position, $\Psi\left(\frac{\gamma z}{l}\right)$ is eigenfunction and eigen $\gamma$ number corresponding to the examined mode shape of the elastic tube - oscillations considered as a rod with fixed ends.

Under the hydroelastic tube, excitation oscillations occur almost always on the first form, for

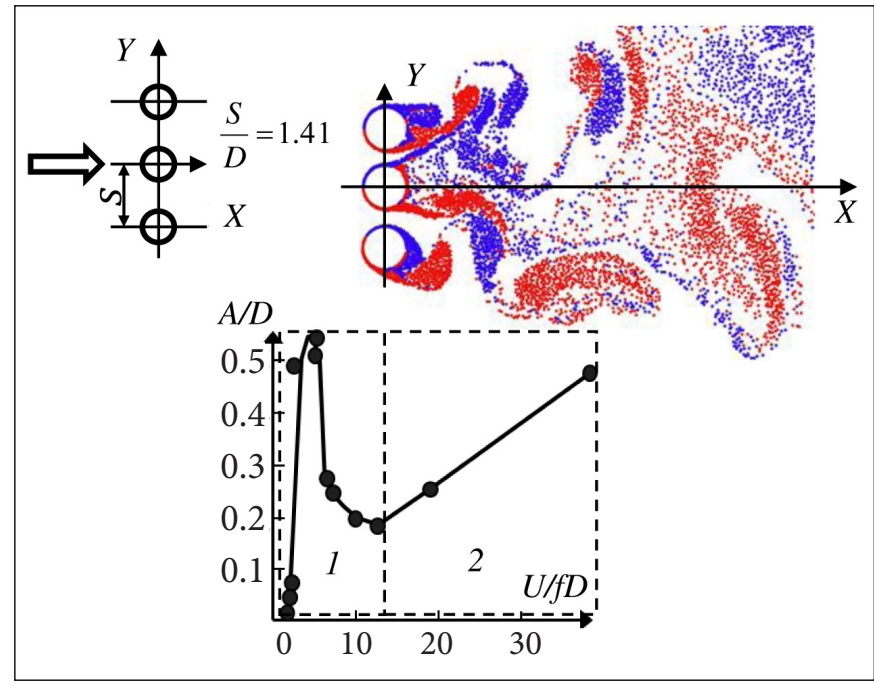

Fig. 2. Numerical experiment by authors for modelling of hydroelastic excitation. Numerical experiment was obtained by viscous vortex domain method (1 - vortex excitation, 2 - hydroelastic excitation). 
which excitation conditions are realised in the first place. Therefore, it can be assumed that $\Psi\left(\frac{\gamma z}{l}\right)$ is corresponding to the main oscillation shape, keeping in mind that a similar consideration can be applied to the higher forms.

Excluding from consideration random forced oscillations excited by random force (excitation type of buffeting), a system of differential equations describing the natural tube oscillations was obtained:

$$
\ddot{x}+2 \xi \omega_{0} \dot{x}+\omega_{0}^{2} x=\mu_{1} c(\tau)
$$

where $\omega_{0}=\omega_{p 1} R / U$ is dimensionless natural frequency of an individual tube, $\omega_{p 1}$ is natural frequency of Flexural vibrations in examined form, $\xi$ is relative damping, $R$ is tube profile radius, $U$ is flow velocity away from the bundle, $\mu_{1}=\rho \cdot \mathrm{R}^{2} / \mathrm{m}$ is dimensionless mass parameter, $\rho$ is fluid density, $C(\tau)$ is hydrodynamic interaction matrix (time-dependent hydrodynamic force matrix), an example of which is shown in Fig. 3, $\tau=t U / R$ is dimensionless time, $\boldsymbol{x}, \dot{\boldsymbol{x}}, \ddot{\boldsymbol{x}}$ are vectors of displacements, velocities, and accelerations of the tube, respectively.

Now, the notion of the linear hydrodynamic coupling matrix $S(p)$ having the dimension $(2 N \times 2 N)$ is introduced, which is obtained from calculating a Laplace integral of hydrodynamic interaction matrix elements $C(\tau)$ :

$$
S(p)=\frac{2 i}{n T} \int_{0}^{n T} C(\tau) e^{-\rho \tau} d \tau
$$

where $p$ is transfer parameter, $n T$ is the number of integration time periods, where $n \rightarrow \infty$.

In computed realizations of hydrodynamic force, $C(\tau)$ spectrum vector corresponding to the profile motion law, a discrete component at profile oscillation frequency, is allocated. For this purpose, realisation $C(\tau)$ is processed by formula (3). At finite-time, averaging equation (3) is implemented approximately.

Equation system (2) with zero initial conditions after variable separation and transformation (3), where $n T \rightarrow \infty$, with assumptions of destabilizing forces linearity has the following form:

$$
\left(p^{2}+2 \cdot \xi \cdot \omega_{0} \cdot p+\omega_{0}^{2}\right) \cdot x=\mu_{1} \cdot S(p) \cdot x,
$$

where $x$ is collective oscillations of the bundle vector.

System (4) solutions determining collective bundle oscillation modes coincide with eigenvectors of matrix $S(p)$. If $\lambda_{j}(p)$ is $j$-th matrix $S(p)$ eigenvalue:

$$
\prod_{j=1}^{2 N}\left[p^{2}+2 \cdot \xi \cdot \omega_{0} \cdot p+\omega_{0}^{2}-\mu_{1} \cdot \lambda_{j}(p)\right]=0 .
$$

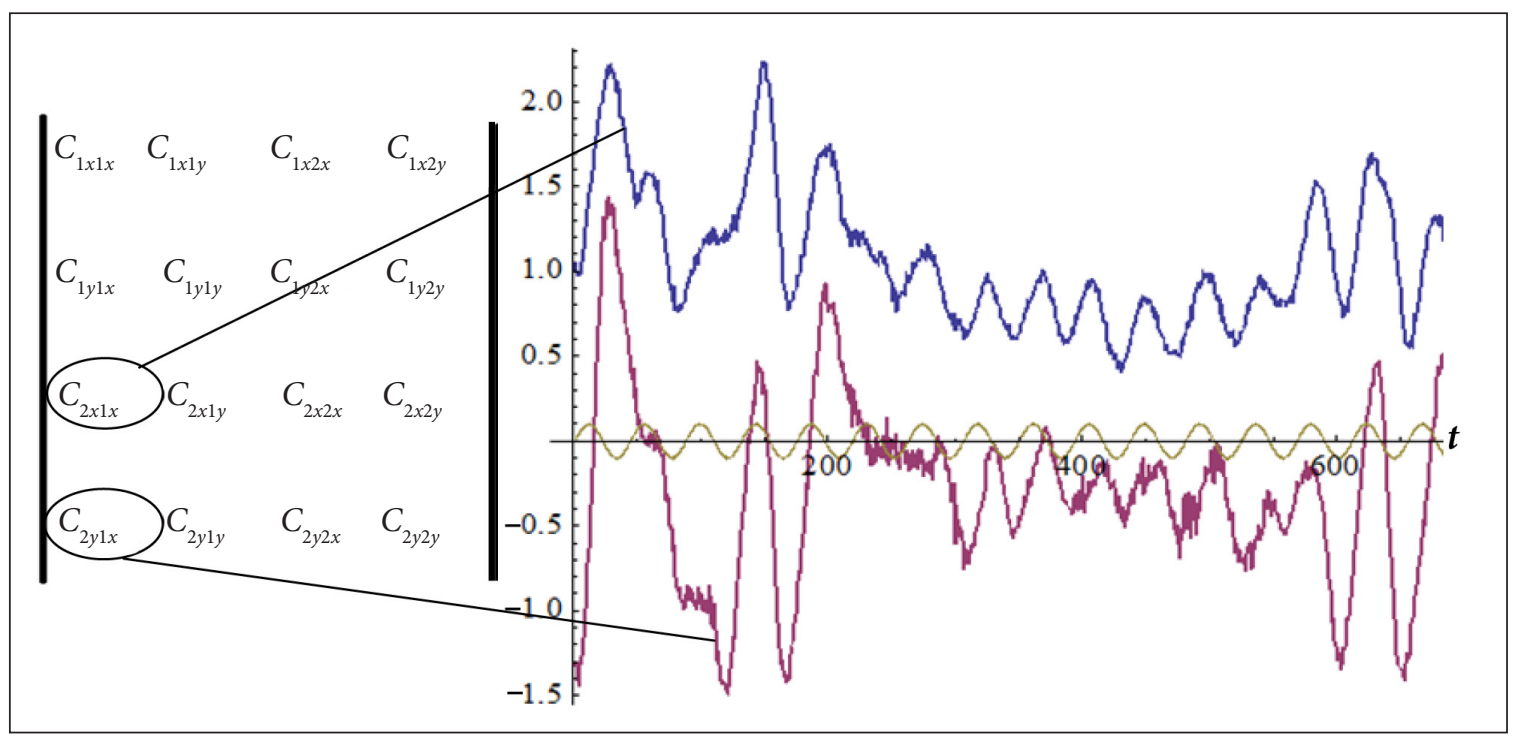

Fig. 3. Hydrodynamic interaction matrix elements (dimension [4×4]) for a row of two tubes. Hydrodynamic force $C_{2 \times 2 y}-$ force acting on the second cylinder in the direction of axis $X$ from fluctuations of the second cylinder in the direction of axis $Y$. Hydrodynamic force $C_{2 \times 2 x}$ - force acting on the second cylinder in the direction of axis $X$ from the fluctuations of the second cylinder in the direction of axis $X$ 
Equation (5) analysis is performed assuming $\xi$ and $\mu_{1}$ are small parameters. For the original system, stable equilibrium is necessary, and it is sufficient that all characteristic equation (5) roots have a negative real part. Applying the developed program, equation (5) is investigated, which determines the stable or unstable state of the system. In order to determine the stability boundary region, it is sufficient to consider only one of the cofactors in equation (5), which includes its eigenvalue $\lambda(p)$ having the maximal imaginary part. On the stability region boundary, where $p=i \omega$ is imaginary value, taking into account only the magnitude not higher than the first order of smallness with respect to small parameters $\xi$ and $\mu_{1}$ applying the Lyapunov criterion from (5), it is obtained:

$$
\begin{aligned}
& \omega^{2}=\omega_{0}^{2}-\mu_{1} \operatorname{Re}\left[\lambda\left(i \omega_{0}\right)\right] \\
& 2 \xi \omega_{0}^{2} / \mu_{1}=\operatorname{Im}\left[\lambda\left(i \omega_{0}\right)\right],
\end{aligned}
$$

Relations (6) determine oscillation frequency for the least stable collective form and critical parameter $2 \xi / \mu_{1}$ value at a given dimensionless frequency. If function $\lambda\left(i \omega_{0}\right)$ is known, then the second of equations (6) allows finding the critical velocity corresponding to the value of $2 \xi / \mu_{1}$ for the investigated bundle.

In the first approximation with relatively small parameters $\xi$ and $\mu_{1}$, the necessary and sufficient condition for stability is

$$
2 \xi / \mu_{1} \geq\left(2 \xi / \mu_{1}\right)_{c r},\left(2 \xi / \mu_{1}\right)_{c r}=\frac{\operatorname{Im}\left[\lambda\left(i \omega_{0}\right)\right]}{\omega_{0}^{2}}
$$

The second of expressions (7) determines the critical value of $\left(2 \xi / \mu_{1}\right)_{c r}$ parameter, i. e. it characterizes the ratio between the damping and destabilizing forces of hydrodynamic interaction on the stability region boundary.

Applying the results of the analysis of characteristic equation (5) for parameters specific to the real bundles, the possibility is approved by numerous experimental data. Firstly, in the real bundles, elastic tubes are slightly damped, i. e. $\xi \ll<1$. Secondly, from experiments it is known that in case of liquid $\left(\mu_{1} ? 1=10^{-1}\right)$ and gas flow $\left(\mu_{1}=10^{-3}\right)$ at hydroelastic excitation oscillations occur at Flexural vibrations of individual tube frequency, i. e. $\omega \approx \omega_{0}$ and, therefore, $\mu_{1} \operatorname{Re}\left[\lambda\left(i \omega_{0}\right)\right]<<\omega_{0}^{2}$. Thus, in real tube-bundles, damping forces and hydrodynamic forces are small compared to elastic forces, and this enables to carry out the analysis with the assumption of small $\xi$ and $\mu_{1}$ parameters.

The obtained stability condition (8) is based on a mathematical model of hydroelastic excitation analysis in a quite general form. Known theoretical models (for example, in works of Alyamovsky [68]), which contain additional assumptions about hydrodynamic interaction types are a special expression (8) case.

For the creation of the numerical experiment, simulating stability of an infinite number of tubes, a hydrodynamic linear interaction matrix obtained for an infinite tube number is necessary.

For the numerical experiment, simulating creation stability of an infinite number of tubes, estimation of a hydrodynamic linear interaction matrix obtained for an infinite row of tubes is necessary. Construction of the specified matrix is rather time-consuming even for a small number of tubes.

Suppose that a matrix for a great number of tubes can be obtained by the considered matrix for three tubes (scheme of the numerical experiment is in Fig. 2), for what we make the following hypothesis: physical characteristics of flow, which determines the non-stationary hydrodynamic forces and hence hydrodynamic linear interaction matrix elements, is the average liquid flow rate speed in the minimum gap between nearby tubes (Fig. 4). The basis for this method is a short-range interaction and hydrodynamic shear symmetry relations in bundles with a regular arrangement in the cross-section. Then, hydrodynamic force value in $N=3$ system differs from the relevant

forces in a system of a great number of tubes by a scale multiplier $\left(\frac{V^{(N)}}{V^{(3)}}\right)^{2}$ where $V^{(N)}$ is a shortrange interaction in the minimum gap between

tubes for a row of $N$ tubes.

The algorithm of the numerical experiment (Fig. 2):

1. One cylinder is oscillating, the other one is stationary. This is repeated $2 \mathrm{~N}$ times separately in $X$ and $Y$ directions, so $C(\tau)$ hydrodynamic connection matrix is received (Fig. 3 ).

2 . Receive a linear hydrodynamic connection matrix $S(p)$, which represents the Laplace image of a hydrodynamic connection matrix. 


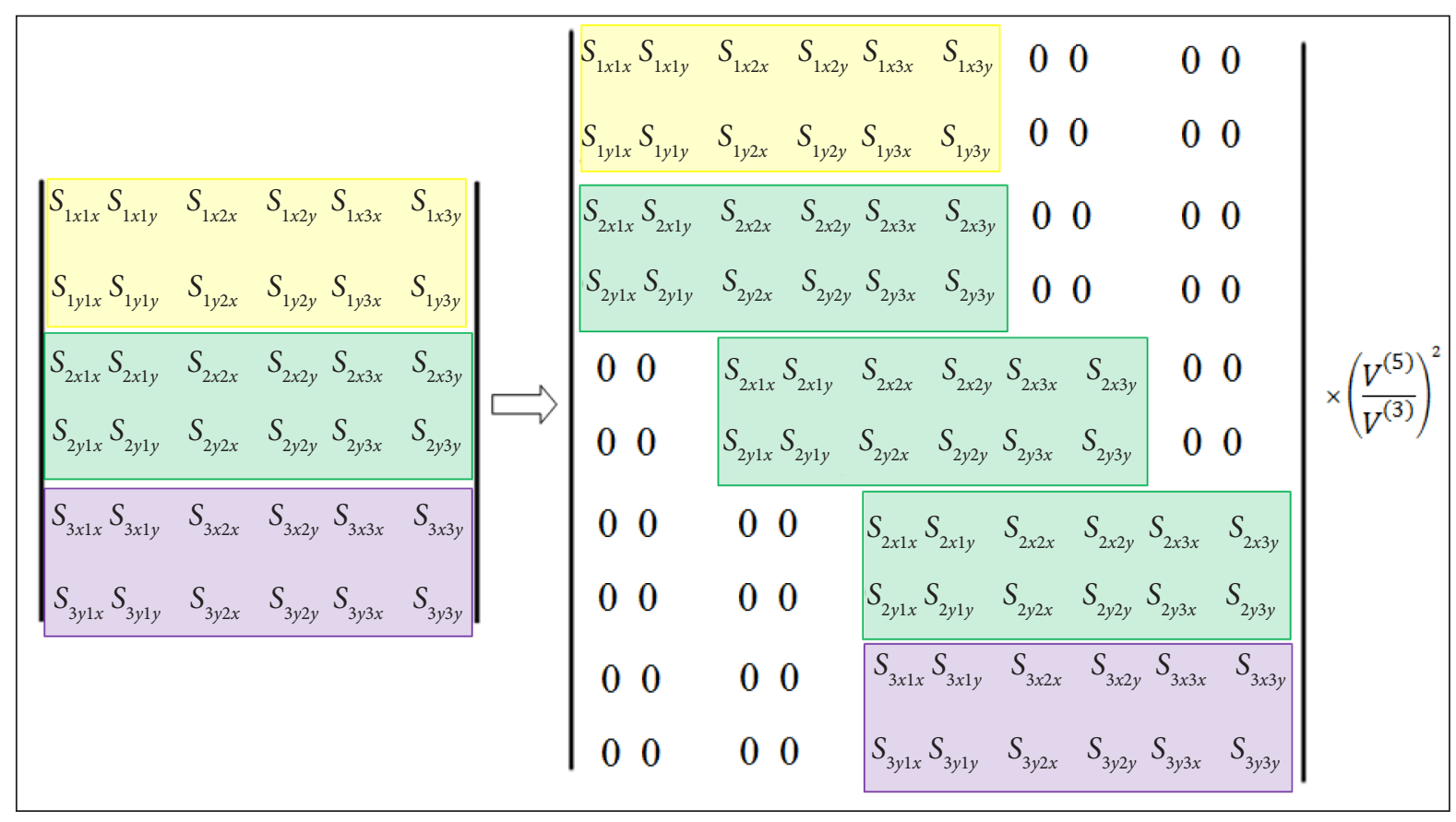

Fig. 4. Reconstruction scheme for linear hydrodynamic interaction matrix for five tubes

3. Find $\lambda_{j}(p)$ eigenvalues of matrix $S(p)$. Out of all eigenvalues, one $\lambda$ with the maximum imaginary part is found. On the stability region border, $p=i \omega$ is imaginary value. The values of accounting parameters $\xi$ and $\mu_{1}$ not higher than the first order of smallness critical parameter value $\left(\frac{2 \xi}{\mu_{1}}\right)_{c r}:\left(\frac{2 \xi}{\mu_{1}}\right)_{c r}=\frac{\operatorname{Im}[\lambda(i p)]}{\omega_{1}^{2}}$ are received.

4. Repeat all points at a different flow velocity and receive stability boundary for the tube-bundle.

\section{RESULTS}

1. The method of discrete vortices (MMDV) was developed and modernized. This method allows visualizing a picture (animation) of a separated cross-flow over complex configuration cylinder in real time.

2. According to the developed algorithm, programs were written for the estimation of hydrodynamic non-stationary forces under separated flow around stationary circular and non-circular profiles oscillating over a given law, profile self-oscillations. Calculation reliability was checked by comparison of the obtained results with available experimental data.
3. A mathematical model for hydroelastic excitation of a bundle of elastic tubes by external cross-flow was worked out. Hydroelastic excitation task is reduced to the unperturbed state of stability analysis of elastic tubes. Based on theoretical investigation of this model, the necessary and sufficient stability conditions expressed through the dimensionless system parameters were received.

4. Received by mathematical model analysis, the necessary and sufficient stability condition was wrote in the visual form through the dimensionless system parameters. The condition allows reasonably carrying out available experimental critical parameter data generalization. Included in stability condition, dimensionless parameters determine similarity criteria for hydroelastic excitation, which is necessary for experimental (and numerical) process in tube-bundle modelling (Fig. 5).

5. The critical velocity values of the flow as a function of the dimensionless parameter (including the value of logarithmic oscillations decrement and dimensionless bundle mass parameter) were defined; this allows an instant troubleshoot of inadmissibility of hydroelastic excitation of already commissioned heat exchanger (Fig. 5). Red dots were obtained by (7) for 15 excitation levels with different frequencies $\omega_{0}$. There $V_{r}=\left(v^{(5)} \pi\right) / \omega_{0}$ is dimensionless parameter of flow velocity. 


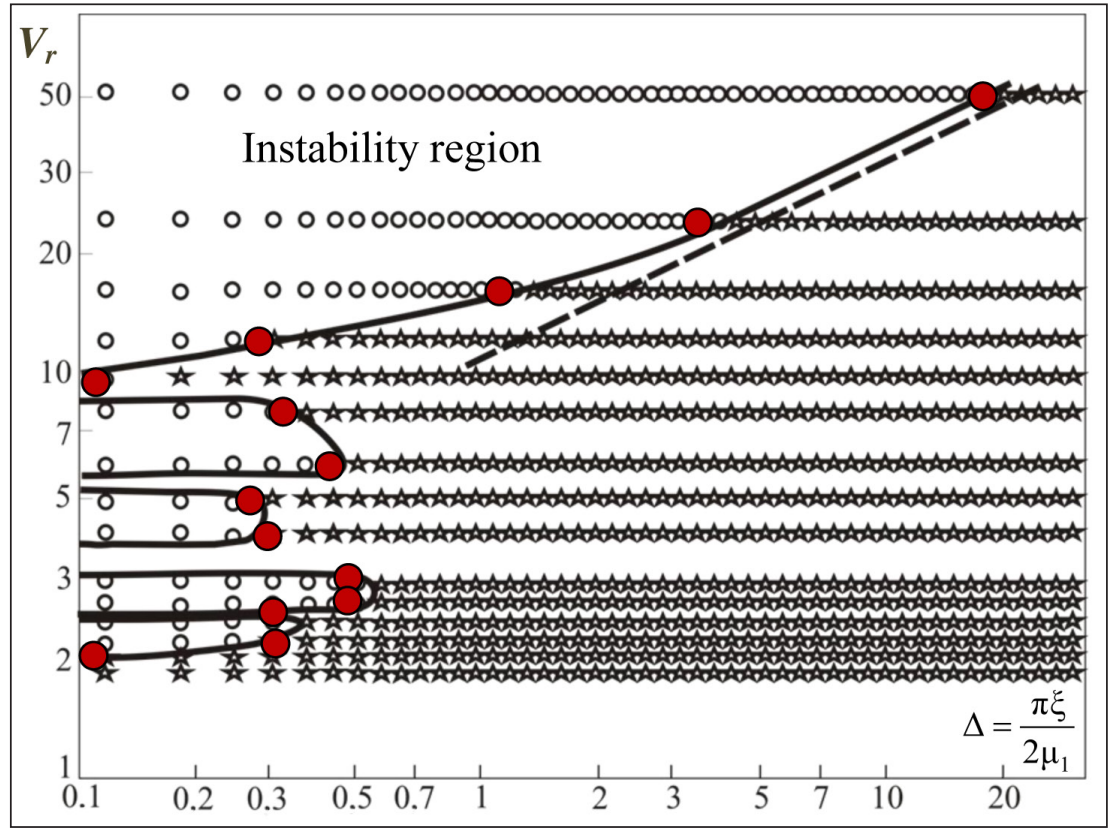

Fig. 5. Stability region boundary for tubes row $(q=S / D=1.41)$ : solid line - authors' calculation for five tube series, dashed line - experiment for infinite number of tubes $[9,10]$

Dashed line on Fig. 5 can be obtained from experimental data [1], [11], [12].

6. A mathematical model of hydroelastic oscillations excitation for the elastic tube-bundle in cross-flow was worked out. The task of hydroelastic excitation investigation is reduced to stability analysis of undisturbed elastic tubes. Based on theoretical investigation of this mathematical model, the necessary and sufficient stability condition expressed through the dimensionless system parameters was received.

7. A method for hydrodynamic forces determining whether bundles consist of a great number of tubes with a regular layout cross-section was proposed.

8. The developed numerical method for hydrodynamic forces and excited tube-bundle oscillations can partly replace or expand costly and time-consuming experimental investigations.

Received 3 June 2015 Accepted 25 November 2015

References

1. Zukauskas A., Ulinskas R., Katinas V. Gidrodinamika i vibracii obtekaemyh puchkov trub. Vilnus: Mokslas, 1984. 312 p.
2. Valles N. G., Masevich A. V., Samolysov A. V. Application of discrete vortices method for separated flow calculation of one- and double-component constructions. Problems of mechanical engineering and automation. 2013. No. 3. P. 42-45.

3. Valles N. G., Masevich A. V., Samolysov A. V. Vortex flow past a stationary and oscillating cylindrical bodies calculation applying method of discrete vortices. Bulletin of the scientific-technical development. 2014. No. 6. P. 31-37.

4. Smirnov L. V., Nikolaev N. Ya. Tube bundles of heat exchangers vibration. Hydrodynamics and convective heat transfer in heat exchangers. Proceedings of the International School-Seminar, 1981, Vilnius. P. 60-71.

5. Kaplunov S. M., Valles N. G., Chentsova N. A., Fursov V. Yu. Mathematical model for the fluidelastic mechanism exciting vibrations in system of blunt bodies placed in cross flow of liquid. Thermal Engineering. 2012. No. 6. P. 44-49.

6. Alamovskiy M. I. Raschet avtokolebaniy trubok teploobmennikov. Energomashinostroenie. 1975. No. 3. P. 33-35.

7. Price S. J. A review of theoretical models for fluidelastic instability of cylinder arrays in crossflow. Journal of Fluids and Structures. 1995. No. 9. P. 463-518. 
8. Lai Y. X. Analysis on dynamic characteristic and flow induced vibration of heat exchanger tube bundles. Doctoral Thesis. Nanjing University of Technology, 2006.

9. Connors H. J. Fluidelastic vibration of tube bundles of heat exchangers. Engineering Design and Technology. 1978. No. 2. P. 95-102.

10. Connors H. J. Flow-induced vibration and wear of steam generator tubes. Nuclear Technology. 1981. Vol. 55. P. 311-331.

11. Chen S. S., Jendrzejczyk J. A. Experiment and analysis of instability of tuberows subject to liquid cross flow. Journal of Applied Mechanics. 1982. Vol. 104. P. 704-709.

12. Blevins R. D., Gibert R. J., Villard B. Experiments on vibration of heat exchanger tube arrays in cross-flow. Transacions of the 6th International Conference on Structural Mechanics in Reactor Technology, paper No. B6/9, Paris, 1981.

Alexey Samolysov, Saveliy Kaplunov, Natalia Valles, Olga Marchevskaya, Elena Dronova

VAMZDŽIŲ RINKLĖS KRITINIO SRAUTO GREIČIO NUSTATYMAS TAIKANT SKAITINIO EKSPERIMENTO METODĄ

Santrauka

Darbas skirtas vamzdžių ir cilindro formos bukųjų objektų pavojingiausių osciliacijos sužadinimo mechanizmų skysčio ar dujų sraute matematiniams modeliams sukurti bei pritaikyti, taip pat efektyvių skaičiavimo metodų aprašymui sukurti.

Autoriai parengè skaitinị hidrodinaminių jègų, sukeliamų srautui atitrūkus, ir vamzdžių rinklių osciliacijų, sužadintų šių jègų, tyrimo metodą.

Metodas pagrịstas sukurto vamzdžių rinklès hidroelastinio osciliacijų sužadinimo mechanizmo taikymu matematiniame skersinio aptekejjimo modelyje. Hidroelastinis sužadinimas sumažinamas iki nesutrikdytos elastinių vamzdžių būsenos stabilumo analizès. Analizė atliekama vadovaujantis destabilizuojančių jègų tiesiškumo prielaida. Atlikus teorinị modeliavimą nustatytos būtinos ir pakankamos stabilumo sąlygos, išreikštos nedimensiniais sistemos parametrais (mase, slopinimu, greičiu).

Parengtas linijinès hidrodinaminès jungties matricos algoritmo skaitinis identifikavimas tam tikroms vamzdžių rinklems. Algoritmo ir programų patvirtinimas pagrịstas skaičiavimų rezultatais bei turimų eksperimentinių duomenų koreliacija.

Pasiūlytas linijinio hidrodinaminio ryšio matricos, vamzdžių rinklèms esant ịprastinio išdèstymo, nustatymo metodas. Jis grindžiamas santykinai mažos, tačiau pakankamos patikimiems rezultatams gauti, vamzdžių rinklès dalies apskaičiavimu.

Raktažodžiai: vamzdžių rinklè, skaitinis eksperimentas, hidroelastinis sužadinimas, atitrūkęs srautas, linijinio hidrodinaminio ryšio matrica 